\title{
OPTIMASI SUHU PENGERINGAN DENGAN MENGGUNAKAN OVEN TERHADAP MUTU LADA HITAM DAN LADA PUTIH BUBUK
}

\author{
RTM Sutamihardja ${ }^{1)}$, Nia Yuliani ${ }^{2)}$, Oktavio Rosani ${ }^{1)^{*}}$ \\ ${ }^{1)}$ Progam Studi Kimia FMIPA Universitas Nusa Bangsa Bogor \\ ${ }^{2)}$ Progam Studi Biologi FMIPA Universitas Nusa Bangsa Bogor \\ Jl. KH Sholeh Iskandar KM 4 Cimanggu Tanah Sereal, Bogor 16166 \\ *email : oktavio.rosani91@ gmail.com
}

\begin{abstract}
Optimization of Drying Temperature Using Oven on Quality of Black Pepper and White Pepper Powder
\end{abstract}

\begin{abstract}
Pepper (Piper Nigrum L) is an Indonesian spice plant widely used for export and import activity. The postharvest process of pepper affected the quality, especially on drying process. One of secondary metabolite compound is piperin. Piperin is an active substance of alkoloid group giving a distinctive spicy flavor to the pepper. Drying process by using the oven could improve the quality of pepper. The results showed that the optimum temperature for white pepper was $85^{\circ} \mathrm{C}$ for 20 minutes with water content of $10.65 \%$, total mold/yeast was $1 \times 10^{4}$ colony/g, and piperin content of $4.58 \%$. For Black pepper, optimum temperature was at $105^{\circ} \mathrm{C}$ for 20 minutes with moisture content of $7.84 \%$, total mold/yeast was $1.3 \times 10^{4}$ colony/g and piperin $5,01 \%$.
\end{abstract}

Keywords : White Pepper, Black Pepper, Piperin Content.

\begin{abstract}
ABSTRAK
Lada (Piper Nigrum L) adalah tanaman rempah Indonesia yang banyak digunakan untuk ekspor dan impor. Proses pasca panen lada yang tidak maksimal menyebabkan kualitas menurun. Lada memiliki senyawa metabolit sekunder berupa piperin. Piperin adalah zat aktif golongan alkoloid yang memberikan cita rasa pedas khas pada lada. Pengeringan dengan menggunakan oven mampu meningkatkan mutu lada. Hasil penelitian menunjukan suhu optimum untuk pengovenan lada putih adalah $85^{\circ} \mathrm{C}$ selama 20 menit dengan kadar air sebesar 10,65\%, AKK $1 \times 10^{4}$ koloni/ g, dan kadar piperin 4,58\%. Lada hitam efektif pada suhu optimum $105^{\circ} \mathrm{C}$ selama 20 menit dengan kadar air sebesar 7,84\%, AKK 1,3 x 10 koloni / g dan kadar piperin 5,01\%.
\end{abstract}

Kata kunci : Lada Putih, Lada Hitam, Kadar Piperin

\section{PENDAHULUAN}

Tanaman lada (Piper nigrum L) adalah salah satu tanaman rempah Indonesia. Cita rasa yang khas membuat lada banyak digunakan untuk konsumsi di dalam negeri maupun ekspor. Lada putih Bangka (Mhuntok) dan lada hitam Lampung adalah jenis lada yang paling terkenal dari Indonesia. Lada pada umumnya digunakan sebagai bumbu masakan dan bahan baku jamu. Lada memiliki banyak khasiat seperti melancarkan peredaran darah, menurunkan kadar kolesterol, memperbaiki sistem pencernaan, anti oksidan dan anti kanker (Hidayat, Nurhasanah \& Usmiati, 2009).
Salah satu proses pengolahan pasca panen lada adalah proses pengeringan. Pengeringan dilakukan setelah proses perendaman biji lada. Pengeringan biji lada yang dilakukan dengan sinar matahari membutuhkan waktu 3 - 10 hari, sehingga kadar air pada biji lada setelah proses pengeringan dengan matahari masih cukup tinggi, sekitar $15-18 \%$. Kadar air yang tinggi sangat rentan terhadap pertumbuhan jamur karena dapat menurunkan dan merusak mutu lada (Mukhlis, 2016).

Kandungan air dan aktivitas air mempengaruhi perkembangan reaksi pembusukan secara kimia dan biologi dalam makanan. Pembusukan biologi dalam makanan diantaranya ditandai oleh 
tumbuhnya jamur. Pada rempah, jamur yang tumbuh berupa kapang dan khamir. Pertumbuhan kapang dan khamir dapat menjadi salah satu indikator kerusakan dalam penyimpanan lada (Chandiko, 2017).

Pertumbuhan mikroorganisme yang tinggi dapat dikurangi dengan pengeringan. Pengeringan dengan menggunakan oven termasuk pengeringan buatan (Utomo, Rahayu, \& Dhiani, 2009). Menurut Sudarmaji (2003) pengeringan adalah proses pengurangan kandungan air suatu bahan hingga mencapai jumlah tertentu. Tujuan pengeringan adalah mengurangi kadar air pada bahan dan menghambat pertumbuhan mikroba. Menurut Hamdiyanti (2017) pengendalian kapang khamir dapat dilakukan dengan menggunakan pemanasan pada suhu di atas $80^{\circ} \mathrm{C}$. Berdasarkan penelitian yang telah dilakukan Chandiko (2017), pengeringan dengan menggunakan sangrai pada suhu $65^{\circ} \mathrm{C}$ dapat mempertahankan kadar piperin lada, tetapi angka kapang khamir pada lada masih tinggi dan melebihi standar yang ditetapkan oleh Badan Pengawasan Obat dan Makanan.

Untuk meningkatkan kualitas lada perlu dilakukan pengeringan dengan menggunakan oven. Selain itu perlu diketahui pula suhu optimal proses pengeringan tersebut. Proses pengeringan dengan oven akan berpengaruh pada kadar air, angka kapang khamir dan kadar piperin. Piperin merupakan senyawa hasil metabolit sekunder golongan akaloid dari lada yang memberikan rasa hangat dan pedas, sehingga perlu diketahui perubahan kadar piperin lada setelah pengovenan.

\section{BAHAN DAN METODE}

\section{Bahan dan Alat}

Bahan utama yang digunakan adalah lada hitam Lampung dan lada putih Bangka yang diperoleh dari pemasok di daerah Jabodetabek. Bahan lainnya adalah Buffer Peptone Water merk Scharlau, Potato Dextrose Agar merk Scharlau dan aquades, etanol $96 \%$.

Peralatan yang digunakan yaitu Neraca Ohauss 210 gram, cawan porselen 30 $\mathrm{mL}$, desikator, oven merk Memmert, oven merk Binder-ED 53, inkubator merk Binder BD-53, laminar air flow, botol semprot, blender, autoklaf. , pemanas berpengaduk, mesin grinder, seperangkat alat refluks dan spektrofotometer UV-Visible (UV-Vis) merk Optizen, mikro pipet dan peralatan gelas lainnya.

\section{Metode \\ Preparasi sampel}

Lada hitam dan lada putih dihaluskan dengan mesin grinder kemudian diayak dengan saringan ukuran $1,25 \mathrm{~mm}$. Lada yang sudah halus dibagi menjadi dua bagian. Bagian pertama tidak dikeringkan dengan oven (tanpa perlakuan). Lada bagian kedua dikeringkan dalam oven menggunakan 3 suhu yang berbeda yaitu $65,85,105^{\circ} \mathrm{C}$ selama 20 menit.

\section{Penetapan Kadar Air (SNI 01-2891-1992)}

Penetapan kadar air dilakukan dengan menimbang sampel halus sebanyak 1 gram, kemudian dimasukkan ke dalam cawan porselen yang sebelumnya telah dikeringkan dan diketahui bobot kosongnya. Sampel dikeringkan selama 3 jam pada suhu $105^{\circ} \mathrm{C}$, dimasukkan ke dalam desikator, dan setelah dingin ditimbang sampai mencapai bobot konstan. Persentase kadar air lada dihitung dengan rumus:

$$
\% \text { Kadar Air }=\frac{\mathrm{B} 1-\mathrm{B} 2}{\mathrm{~B}} 100 \%
$$

Keterangan:

B1 = Bobot cawan + isi sebelum dikeringkan

$\mathrm{B} 2=$ Bobot cawan + isi setelah dikeringan

$\mathrm{B}=$ Bobot sampel

\section{Penetapan Kapang dan khamir (SNI 01- 2897-1992)}

\section{a. Sterilisasi Kering Alat}

Alat gelas yang akan digunakan untuk analisis kapang dan khamir dibungkus dengan aluminium foil,dan dikeringkan dalam oven selama 1 jam pada suhu $180^{\circ} \mathrm{C}$.

\section{b. Pembuatan Larutan Pengencer Buffer Pepton Water (BPW)}

Pembuatan larutan pengencer dilakukan dengan menimbang BPW sebanyak 4,5 gram lalu dilarutkan dalam $500 \mathrm{~mL}$ aquades 
dan diaduk diatas pemanas berpengaduk hingga homogen. Larutan BPW yang sudah homogen dituang sebanyak $45 \mathrm{~mL}$ ke dalam erlenmeyer dan dituang sebanyak $9 \mathrm{~mL}$ ke dalam tabung reaksi. Erlenmeyer dan tabung reaksi disumbat dengan kapas dan ditutup dengan aluminium foil, lalu disterilkan dengan autoklaf selama 15 menit pada suhu $121^{\circ} \mathrm{C}$

\section{c. Pembuatan Media Agar Potato Dextrose Agar (PDA)}

Pembuatan media agar dilakukan dengan cara menimbang PDA sebanyak 3,9 gram lalu dilarutkan dalam $100 \mathrm{~mL}$ aquades dan diaduk diatas pemanas berpengaduk hingga mendidih. PDA dituang ke dalam tabung reaksi sebanyak 12- $15 \mathrm{~mL}$. Tabung reaksi disumbat dengan kapas dan ditutup dengan aluminium foil, disterilkan dengan autoklaf selama 15 menit pada suhu $121^{\circ} \mathrm{C}$.

\section{d. Analisis Kapang Khamir}

Lada putih dan lada hitam yang sudah halus ditimbang sebanyak 5 gram dan dituang ke larutan BPW $45 \mathrm{~mL}$, dikocok hingga homogen dan didiamkan hingga sampel mengendap. Larutan berisi sampel dipipet sebanyak $1 \mathrm{~mL}$ dengan mikropipet, dituang kedalam tabung reaksi pengenceran $10^{-1}$, sampai pengenceran $10^{-5}$. PDA dengan suhu $45^{\circ} \mathrm{C}$ dituangkan ke dalam cawan petri sebanyak $12 \mathrm{~mL}$, dihomogenkan dan dibiarkan hingga media memadat. Cawan petri dimasukan dalam inkubator dengan suhu $25 \pm 2^{\circ} \mathrm{C}$ selama $5 \times 24$ jam. Untuk analisis sterilitas media dilakukan dengan menuangkan media PDA dan pengencer dalam cawan petri dan dibiarkan memadat sebagai kontrol.

\section{e. Perhitungan Angka Kapang dan Khamir (BPOM, 2006)}

Analisis uji kapang dan khamir dilakukan secara duplo pada setiap tingkat pengenceran. Penetapan angka kapang khamir dilakukan dengan cawan petri yang menunjukan jumlah antara 10-150 koloni. Cawan petri yang terbentuk 10-150 koloni dengan tingkat pengenceran yang sama, maka jumlah koloni per masing-masing cawan petri dihitung kemudian jumlah kedua koloni dikalikan dengan faktor pengencerannya kemudian diambil rata-rata. Hasil rata-rata tersebut dibaca sebagai nilai angka kapang dan khamir dalam setiap gram atau $\mathrm{mL}$ sampel.

Angka kapang dan khamir :

$$
\text { Rata- rata (koloni) x } 10^{\mathrm{n}}
$$

Keterangan:

$$
\mathrm{n} \text { : Faktor pengenceran }
$$

\section{f. Pembuatan Larutan Standar (Nurazizah, Aminingsih, \& Mulyati, 2017)}

Piperin ditimbang sebanyak $5 \mathrm{mg}$, dimasukkan ke dalam labu ukur $50 \mathrm{~mL}$, dilarutkan dalam etanol $96 \%$ sampai tanda tera. Sebanyak $10 \mathrm{~mL}$ larutan tersebut dipipet ke dalam labu ukur $100 \mathrm{~mL}$, ditambahkan etanol 96\% sampai tanda tera. Dari standar induk tersebut dibuat deret standar konsentrasi $10,5,1,0,75$ dan 0,5 $\mathrm{mg} / \mathrm{L}$.

\section{g. Pembuatan Larutan Uji Piperin (SNI 0004 : 2013)}

Penentuan kadar piperin dilakukan dengan ekstraksi menggunakan etanol dan pengukuran absorbansi pada panjang gelombang $343 \mathrm{~nm}$ dengan alat spektrofotometer UV-VIS. Sampel lada sebanyak $\pm 0,5$ gram direfluks dengan etanol sebanyak $50 \mathrm{~mL}$ pada pendingin tegak selama 3 jam. Setelah refluks, sampel lada didinginkan dan disaring ke dalam labu takar $100 \mathrm{~mL}$ dan ditepatkan dengan etanol, lalu dihomogenkan (larutan 1). Larutan 1 dipipet sebanyak $5 \mathrm{~mL}$, dimasukkan ke dalam labu takar $50 \mathrm{~mL}$ ditepatkan dengan etanol (Larutan 2). Larutan 2 dipipet sebanyak $5 \mathrm{~mL}$ dimasukkan ke dalam labu takar $25 \mathrm{~mL}$, ditepatkan dengan etanol, dan dihomogenkan. Absorbansi sampel dapat diukur pada panjang gelombang $343 \mathrm{~nm}$ dengan etanol sebagai blanko.

Kadar piperin yang dinyatakan sebagai persentase bobot berdasarkan bobot kering sebagai berikut :

$\%$ Kadar piperin:

$$
\frac{\mathrm{A}}{\mathrm{A} 1 \mathrm{~cm} 1 \%} \times \frac{50}{5} \times \frac{25}{5} \times \frac{100}{\mathrm{M}} \times \frac{100}{100-\mathrm{KA}}
$$


Keterangan :

M adalah bobot contoh uji (g)

KA adalah kadar air contoh uji (\%)

A adalah absorbansi larutan contoh

$\mathrm{A}_{1} \mathrm{~cm}^{1 \%}$ adalah absorbansi pada $343 \mathrm{~nm}$

dari $1 \%$ larutan piperin yaitu 1238

\section{HASIL DAN PEMBAHASAN}

\section{Pengeringan dengan Oven}

Hasil pengeringan dengan oven tidak menunjukkan perubahan warna yang signifikan. Perubahan warna terjadi karna adanya reaksi browning pada lada (Gambar 1). Reaksi browning pada lada merupakan proses enzimatis yang dikatalisasi oleh enzim polifenolase dengan adanya oksigen. Pencoklatan enzimatis terjadi karena komponen fenolik terkonversi menjadi melanin coklat yang dikatalisis oleh enzim polifenoloksidase (Weller, Sims, Matthews, Bates \& Brecht, 1997). Penghambatan pencoklatan enzimatis dapat dilakukan dengan beberapa metode, salah satunya dengan perlakuan fisik seperti pemanasan dengan suhu yang stabil (Nurjannah, 2008).

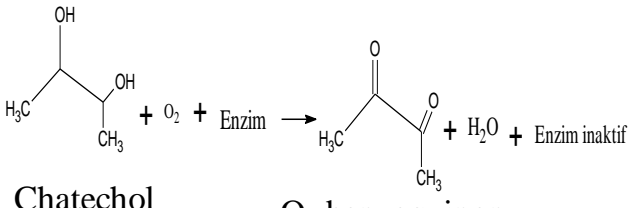

Chatechol

O- benzoquinon

\section{Gambar 1. Reaksi browning}

Suhu oven lebih stabil dibandingan dengan suhu sangrai. Hal ini menyebabkan lada yang dioven mempunyai kenampakan visual yang lebih baik dibandingkan dengan lada yang dikeringkan dengan sangrai. Pengeringan lada dengan sangrai menyebabkan perubahan warna yang signifikan.

\section{Kadar Air}

Analisis kadar air dilakukan untuk mengetahui kandungan air di dalam lada. Kadar air lada putih sebelum pengeringan dengan oven lebih tinggi dibandingkan dengan lada hitam (Gambar 2). Hal ini disebabkan oleh proses penyimpanan lada. Apabila lada disimpan di ruangan yang kelembabannya relatif tinggi, maka lada akan menyerap sejumlah air dari lingkungan untuk menyesuaikan kelembaban relatifnya karena komoditas rempah-rempah bersifat higroskopis. Penyimpanan pada suhu tinggi $\left( \pm 40^{\circ} \mathrm{C}\right)$ dapat menyebabkan ruang penyimpanan semakin kering sehingga kadar air bahan menurun (Sembiring dan Hidayat, 2012). Semakin tinggi suhu pengeringan, maka kadar air akan semakin rendah. Perubahan massa air akan terjadi saat kandungan air pada pangan telah sampai pada kondisi jenuh (Karyadi, Lumbanbatu \& Rahayoe, 2009).

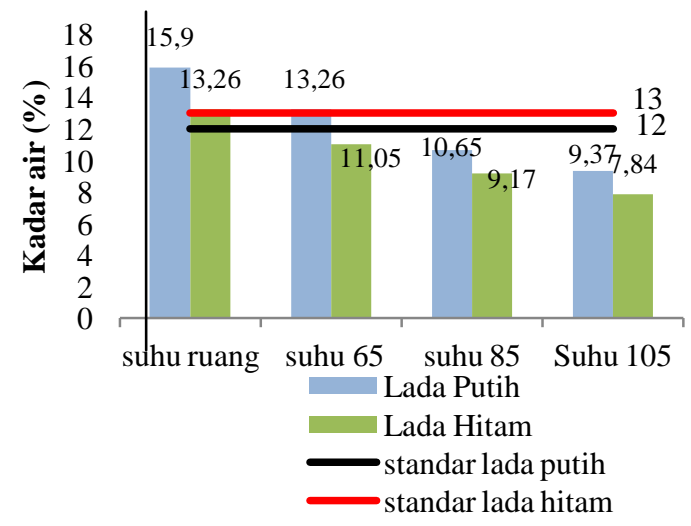

Gambar 2. Kadar air pada lada

\section{Angka Kapang Khamir (AKK)}

Hasil pengamatan menunjukan koloni kapang berbentuk benang halus yang terlihat ke permukaan, sedangkan khamir berbentuk koloni seperti tetesan susu kental manis. Kapang terdapat pada lada dalam jumlah yang lebih banyak dibandingkan dengan khamir (Gambar 3 dan 4). Hal ini disebabkan karena kapang bereproduksi dalam jumlah yang banyak, berukuran kecil, ringan, dan tahan terhadap keadaan kering (Firmansyah, 2013).

Pengeringan dengan oven bertujuan untuk menurunkan jumlah air yang terdapat dalam pangan, sebagian air dari pangan diuapkan, penguapan air dapat menurunkan Aw pangan sehingga Aw berada dibawah kisaran pertumbuhan mikroba $(\mathrm{Aw}<0,60)$. Pengovenan pada lada merupakan salah satu cara pengeringan yang efektif dalam menurunkan kadar air dan memperlambat tumbuhnya mikroba (Kusnandar, 2010). 
Proses pengovenan dengan suhu yang semakin tinggi mengakibatkan nilai AKK semakin rendah. AKK pada lada hitam jauh lebih tinggi dibandingan dengan AKK lada putih meskipun kadar air pada lada hitam lebih kecil. Hal ini disebabkan oleh daging buah lada yang mengandung selulosa. Sehingga kapang khamir lebih banyak terdapat di lada hitam (Untari, 1993).

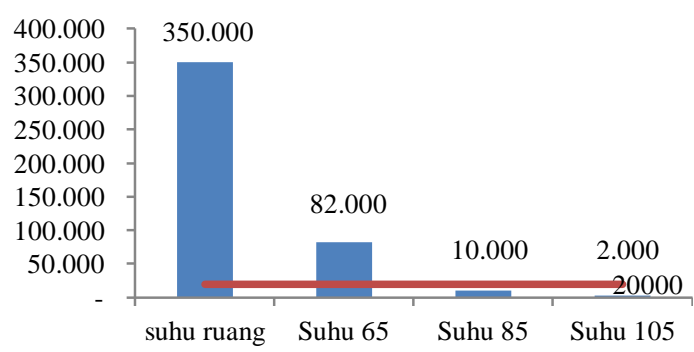

Lada Putih

$\longrightarrow$ standar AKK BPOM

Gambar 3. Angka Kapang Khamir pada Lada Putih

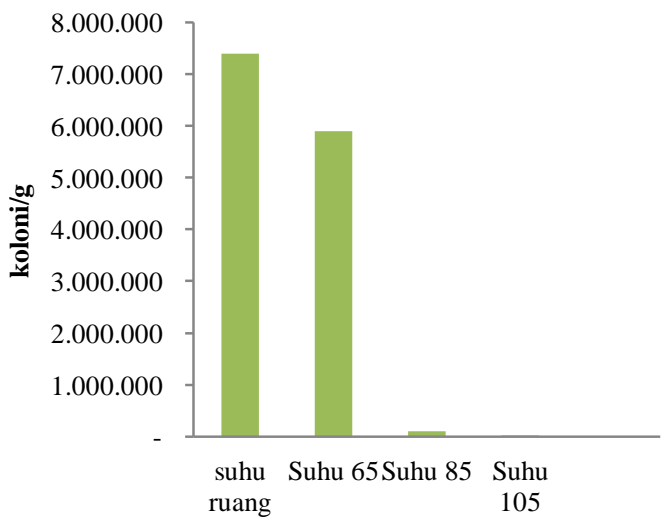

Gambar 4. Angka Kapang Khamir pada Lada Hitam

\section{Kadar Piperin}

Hasil analisis kadar piperin pada lada hitam dan lada putih tidak menunjukan perubahan yang signifikan. Kadar piperin pada lada menurun setelah proses pengovenan dengan suhu $105^{\circ} \mathrm{C}$. Hal ini disebabkan oleh aktivitas kapang khamir yang menurun. Kandungan air yang lebih banyak memungkin kapang khamir untuk melakukan aktivitas yang menghasilkan reaksi enzimatis dan mempengaruhi reaksi hidrolisis. Semakin rendah enzim yang dihasilkan, maka kadar piperin semakin tinggi. Hal ini sesuai dengan pendapat Rachmat (1991), lada bersifat higroskopis sehingga menarik air dari udara dan memperbesar kemungkinan untuk piperin terhidolisis. Semakin tinggi kadar air dalam lada, maka kadar piperin akan semakin kecil karena piperin mudah terhidrolisis (Gambar 6) menjadi asam piperat dan piperidin yang mempunyai rasa kurang pedas.

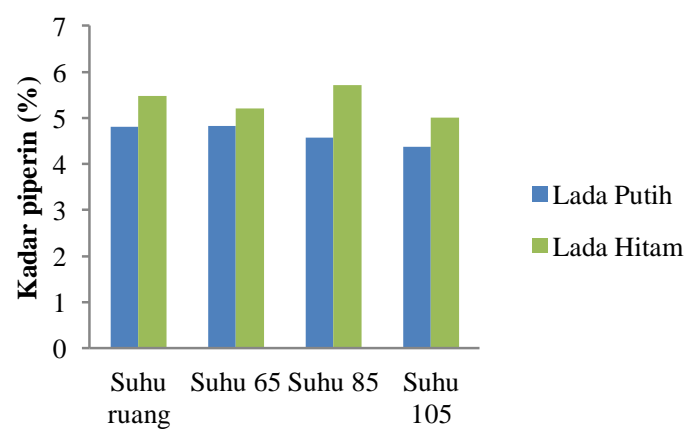

Gambar 5. Kadar piperin pada lada putih dan lada hitam

Kadar piperin pada lada hitam lebih besar dari pada kadar piperin lada putih. Hal ini dikarenakan pada saat proses pengeringan pasca panen, biji lada hitam dikeringkan bersama daging buah lada. Di dalam daging buah lada hitam terdapat senyawa chavicin yang merupakan piperidida asam tidak jenuhdan merupakan isomer piperin. Golongan piperidida adalah komponen komponen yang berbeda dengan piperin dalam bentuk komponen asam yang menimbulkan rasa pedas dan biasanya mengandung asam isopiperat dan asam isochavicinat (Rachmat, 1991). 


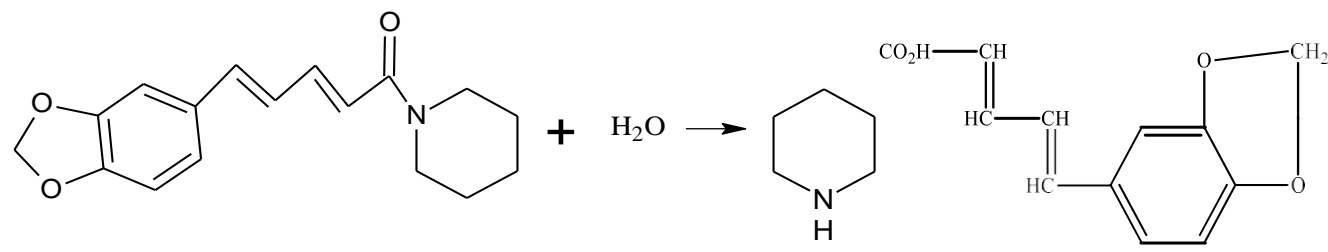

Gambar 6. Reaksi hidrolisis piperin

\section{KESIMPULAN}

Suhu optimum untuk pengovenan lada putih adalah $85^{\circ} \mathrm{C}$ selama 20 menit dengan kadar air sebesar 10,65\%, AKK 1 x $10^{4}$ koloni/ g, dan kadar piperin 4,58\%. Lada hitam efektif pada suhu optimum $105^{\circ} \mathrm{C}$ selama 20 menit dengan kadar air sebesar 7,84\%, AKK 1,3 x $10^{4}$ koloni / g dan kadar piperin 5,01\%.

\section{DAFTAR PUSTAKA}

Badan Pengawas Obat dan Makanan. (2006). Pedoman Cara Pembuatan Obat yang Baik. BPOM RI.

Badan Standardisasi Nasional. (1992). Cara Uji Cemaran Mikroba, SNI: 012897-1992 2. Badan Standardisasi Nasional.

Badan Standardisasi Nasional. (1992). Cara Uji Makanan dan Minuman, SNI: 01-2891-1992.

Badan

Standardisasi Nasional.

Badan Standardisasi Nasional. (2013). Lada Putih, SNI 0004 : 2013. Badan Standarisasi Nasional.

Chandiko, W. (2017). Kadar Piperin Lada Hitam Bubuk dan Putih Setelah Penyangraian (Skripsi). Universitas Nusa Bangsa, Bogor.

Firmansyah, W.E. (2013). Mikrobiologi Umum (Tugas). Universitas Brawijaya. Malang.

Hamdiyati, Y. (2017). Pertumbuhan dan Pengendalian Mikroorganisme II
(Diktat Mikrobiologi). Jakarta.

Hidayat, T., Nurhasanah, N. \& Usmiati, S. (2009). Analisis Teknis dan Finansial Paket Teknologi Pengolahan Lada Putih (White Pepper) Semi Mekanis. Bul. Littro, 20(1), 77-91.

Karyadi, J.N.W., Lumbanbatu, J., \& Rahayoe, S. (2009). Pengaruh Suhu dan Lama Penyangraian terhadap Sifat Fisik-Mekanis Biji Kopi Robusta. Makalah Bidang Teknik Produk Pertanian, 217225

Kusnandar, F. (2010). Memahami Aktifitas dan Hubungan Dengan Keawetan Pangan. Bogor. Diakses dari http://itp.fateta.ipb.ac.id/id

Mukhlis, A.M.R. (2016). Pengeringan Spouted Bed Lada Putih (Piper nigrum L) Dengan Perlakuan Preheating Gelombang Mikro (Tesis). Sekolah Pascasarjana Institut Pertanian Bogor, Bogor.

Nurazizah, L., Aminingsih, T., \& Mulyati, A.H. (2017). Uji aktivitas Antibakteri dan Analisis Kadar Piperin Ekstrak Buah Cabe Jawa (Piper retrofractum Vahl). Universitas Pakuan. Bogor.

Nurdjannah, N., \& Hoerudin. (2008). Pengaruh Perendaman Dalam Asam Organik dan Metoda Pengeringan Terhadap Mutu Lada Hijau Kering. Bul. Littro,. XIX(2), $181-196$. 
Rachmat, E. 1991. Kajian Perubahan Karakteristik Mutu lada Hijau Kering (Dehydrated Green Pepper) dengan variasi penambahan asam sorbated $C A M$ pengeringan (Skripsi). Institut Pertanian Bogor, Bogor.

Sembiring, B.S. \& Hidayat, T. (2012). Perubahan Mutu Lada Hijau Kering Selama Penyimpanan Pada Tiga Macam Kemasan dan Tingkatan Suhu. Jurnal Littri, 18(3).doi.org/10.21082/littri.v18n3 $.2012 .115 \% 20-\% 20124$

Sudarmadji, K. (2003). Pengeringan Lada Putih (Piper nigrum Linn.) Menggunakan Oven Gelombang Mikro (Mikrowave Oven) (Skripsi). Institut Pertanian Bogor, Bogor.
Untari, R. (1993). Pengaruh Fumigasi Fhosfin pada Mutu Mikrobiologi Lada (Skripsi). Institut Pertanian Bogor, Bogor.

Utomo, A. D., Rahayu, W. S. \& Dhiani, B. A. (2009). Beberapa Metode Pengeringan Terhadap Kadar Flavonoid Herba Sambiloto (Andrographis paniculata). Pharmacy, 06(01), 58-68. doi: 10.30595/pji.v6i1.402

Weller, A.,. Sims, C.A., Matthews, R.F., Bates, R.P. \& Brecht, J.K. (1997). Browning Susceptibility and Changes in Compotition during Storage of Carambola Slices. Journal of Food Science, 62(2), 256-260. 